\title{
ASSESSING THE INOPERABILITY OF BRONCHIAL CARCINOMA BY ANGIOCARDIOGRAPHY*
}

\author{
BY \\ B. V. SLESSER, R. G. BRITT, AND J. L. FREER \\ From the Departments of Surgery and Radiology, Leicester Chest Unit
}

(RECEIVED FOR PUBLICATION FEBRUARY 2, 1954)

The assessment of inoperability of bronchial carcinoma by angiocardiography has received little attention in this country, and it is the purpose of this paper to discuss the value of this investigation by analysing our results in 31 cases at Leicester Chest Unit. Since the introduction of angiocardiography by Robb and Steinberg in 1938 many authors have described its use in the differential diagnosis of lesions of the lungs and mediastinum, but it is not intended to discuss this aspect.

The possibility of assessing the operability of bronchial neoplasm by angiocardiography was first suggested by Steinberg, Dotter, and Andrus (1950). Dotter and Steinberg in 1952 gave further details and results of their methods. In addition, Andersen, Andersen, Eltorm, Poulsen, Glistrup, and Petersen (1951) mentioned the use of this technique in the assessment of operability in two cases of bronchial carcinoma and in one case of mediastinal tumour (nodal metastases from a breast carcinoma).

\section{TeChNique}

Angiocardiography was performed in the supine position using an automatic serial changer which permitted eight films to be exposed in 10 seconds. The radiographic factors used were $75-85 \mathrm{kV}$, $300 \mathrm{~mA}, 0.1$ second with a tube-film distance of 36 in. using a stationary grid. A preliminary film was taken to ensure radiographs of diagnostic quality. The patients were prepared for the investigation with "omnopon" and scopolamine ; $50 \mathrm{ml}$. of the $70 \%$ diodone solution was injected as rapidly as possible through a wide-bore cannula in the ante-cubital vein. No untoward reaction followed the injection in any patient of the series.

\section{RADIOLOGY}

In the angiocardiographic assessment of inoperability we have followed the principles of Dotter

* Based on a paper given by Miss B. V. Slesser to the annual meeting of the Association of Thoracic Surgeons of Great Britain and Ireland in November, 1953. and Steinberg (1952), and in the present series we have made our decisions on the following criteria.

(1) Evidence of partial obstruction or irregular filling of, or actual filling defects in, the superior vena cava or left innominate vein, and associated back pressure in the small venous tributaries not normally filled on an angiocardiogram and not detected clinically ; (2) partial or complete occlusion or irregular filling of the main right pulmonary artery proximal to its bifurcation into upper and lower branches ; (3) partial or complete occlusion or deformity of the main left pulmonary artery within $1.5 \mathrm{~cm}$. of its origin from the main trunk. The left pulmonary artery has a long extrapericardial course and involvement by new growth can more often be expected on that side.

Displacement, deformities, partial or complete occlusion of the branches of the main arteries in no way help in assessing operability beyond suggesting that some difficulty may be met with in ligation of the main trunk, requiring intrapericardial ligation. Only deformities of the main pulmonary arteries and great veins are diagnostic of inoperability. Lateral or medial deviation of the vena cava due to mediastinal glands is not necessarily a sign of inoperability.

In 31 cases there were 11 instances where angiocardiography suggested inoperability on account of a block or deformity of the main pulmonary artery stem, or deformity of the superior vena cava, and thoracotomy confirmed these findings. The remaining 20 cases showed normal great vessels, or block or deformity of the branch artery only, and the operability of this group was confirmed at operation (Tables I and II).

\section{Discussion}

Any investigation which may obviate a useless thoracotomy is worthy of a trial. This operation is not only time consuming, but, we feel, actively harms the patient, accelerating his downhill course and causing much discomfort, mental and physical, 
TABLE I

ANGIOCARDIOGRAPHIC FINDINGS IN 20 CASES OF BRONCHIAL CARCINOMA OPERABLE AT THORACOTOMY

\begin{tabular}{|c|c|c|c|}
\hline Cases & Site of Lesion & Angiocardiographic Findings & Thoracotomy \\
\hline 1 & Small mass $\mathbf{R}$. hilum & $\begin{array}{l}\text { Normal superior vena cava and main pulmonary } \\
\text { artery branches }\end{array}$ & Pneumonectomy \\
\hline 2 & Mass L. upper lobe & $\begin{array}{l}\text { L. main pulmonary artery normal, non-filling } \mathrm{L} \text {. } \\
\text { upper lobe branches, filling } \mathrm{L} \text {. lower lobe branches }\end{array}$ & $\begin{array}{l}\text { Pneumonectomy, large carcinoma in upper part of } \\
\text { lung root extending along pulmonary artery to }\end{array}$ \\
\hline 3 & $\begin{array}{l}\text { Mass R. hilum with } \\
\text { atelectasis pectoral } \\
\text { segment R. upper lobe }\end{array}$ & $\begin{array}{l}\text { Normal superior vena cava, block upper lobe } \\
\text { branch R. pulmonary artery, normal lower branch }\end{array}$ & $\begin{array}{l}\text { Pneumonectomy, intrapericardial dissection, } \\
\text { growth extending a fair distance along } \mathrm{R} \text {. pul- } \\
\text { monary artery }\end{array}$ \\
\hline 4 & $\begin{array}{l}\text { Mass L. hilum, atelec- } \\
\text { tasis L. lower lobe. }\end{array}$ & $\begin{array}{l}\text { Normal superior vena cava and main L. pulmonary } \\
\text { artery }\end{array}$ & Pneumonectomy \\
\hline 5 & $\begin{array}{c}\text { Partial atelectasis } R \text {. } \\
\text { upper lobe with cavity }\end{array}$ & $\begin{array}{l}\text { No1 mal superior vena cava, bifurcation } R \text {. pulmonary } \\
\text { artery seen, block apical branches } R \text {. upper lobe } \\
\text { beyond origin }\end{array}$ & Pneumonectomy \\
\hline 6 & $\begin{array}{l}\text { Mass L. hilum } \\
\text { Atelectasis L. upper lobe }\end{array}$ & $\begin{array}{l}\text { Normal superior vena cava and pulmonary artery } \\
\text { Normal superior vena cava, L. upper lobe branches } \\
\text { of pulmonary artery blocked, L. lower lobe } \\
\text { branches filled }\end{array}$ & $\begin{array}{l}\text { Pneumonectomy } \\
\text { Pneumonectomy, intrapericardial dissection of } \\
\text { superior veins }\end{array}$ \\
\hline 8 & Atelectasis L. lower lobe & Normal superior vena cava and pulmonary artery & Pneumonectomy \\
\hline 9 & $\begin{array}{l}\text { Mass dorsal apical seg- } \\
\text { ment L. lower lobe }\end{array}$ & $\begin{array}{l}\text { Normal superior vena cava, normal main } L \text {. pul- } \\
\text { monary artery, poor filling L. upper lobe bran- } \\
\text { ches, non-filling L. lower lobe branches }\end{array}$ & Pneumonectomy \\
\hline 10 & Atelectasis L. upper lobe & $\begin{array}{l}\text { Normal superior vena cavo, ? filling defect upper } \\
\text { aspect L. main pulmonary artery, non-filling L. } \\
\text { upper lobe branches }\end{array}$ & $\begin{array}{l}\text { Pneumonectomy, growth spreading along } L \text {. pul- } \\
\text { monary artery which had to be ligated flush with } \\
\text { main pulmonary artery }\end{array}$ \\
\hline 11 & $\begin{array}{l}\text { Mass dorsal apical seg- } \\
\text { ment L. lower lobe }\end{array}$ & $\begin{array}{l}\text { Normal superior vena cava, normal main pulmonary } \\
\text { artery. incomplete filling } L \text {. upper lobe branches, } \\
\text { reasonable filling L. lower lobe branches }\end{array}$ & Pneumonectomy \\
\hline 12 & Mass L. upper lobe & $\begin{array}{l}\text { Normal superior vena cava, ? narrowing L. pul- } \\
\text { monary artery proximal to bifurcation, no upper } \\
\text { lobe branch filling }\end{array}$ & $\begin{array}{l}\text { Pneumonectomy, intrapericardial dissection due to } \\
\text { growth round } L \text {. pulmonary artery. }\end{array}$ \\
\hline 13 & L. hilar mass & $\begin{array}{l}\text { Normal superior vena cava, normal filling } L \text {. main } \\
\text { pulmonary artery, partial block } \mathbf{L} \text {. upper lobe } \\
\text { branches }\end{array}$ & Pneumonectomy \\
\hline 14 & Atelectasis L. upper lobe & $\begin{array}{l}\text { Normal superior vena cava, normal L. main pul- } \\
\text { monary artery, poor filling L. upper lobe branches }\end{array}$ & Pneumonectomy \\
\hline 15 & $\begin{array}{l}\text { Mass dorsal apical seg- } \\
\text { ment } L \text {. upper lobe }\end{array}$ & $\begin{array}{l}\text { Normal superior vena cava, normal filling } \mathbf{L} \text {. main } \\
\text { pulmonary artery, patchy filling } L \text {. lower lobe } \\
\text { branches }\end{array}$ & Pneumonectomy \\
\hline 16 & $\begin{array}{l}\text { Large mass dorsal apical } \\
\text { segment L. lower lobe }\end{array}$ & $\begin{array}{l}\text { Normal superior vena cava, normal filling } L \text {. main } \\
\text { pulmonary artery and } L \text {. upper lobe branches, } \\
\text { poor filling L. lower lobe branches }\end{array}$ & Pneumonectomy \\
\hline 17 & $\begin{array}{l}\text { Mass dorsal apical seg- } \\
\text { ment } R \text {. lower lobe and } \\
\mathbf{R} \text {. hilar mass }\end{array}$ & $\begin{array}{l}\text { Normal superior vena cava, normal main pulmonary } \\
\text { artery }\end{array}$ & Pneumonectomy, large gland mass dissected \\
\hline 18 & Mass L. hilum & $\begin{array}{l}\text { Normal superior vena cava and main pulmonary } \\
\text { artery, block of some basal branches }\end{array}$ & Pneumonectomy \\
\hline 19 & $\begin{array}{l}\text { Mass } \mathbf{R} \text {. hilum with ate- } \\
\text { lectasis } \mathbf{R} \text {. lower lobe }\end{array}$ & $\begin{array}{l}\text { Normal superior vena cava and main pulmonary } \\
\text { artery, deformity branches } R \text {. pulmonary artery } \\
\text { close to origin }\end{array}$ & $\begin{array}{l}\text { Pneumonectomy, large mass of glands anterior to } \\
\text { pulmonary artery }\end{array}$ \\
\hline 20 & $\begin{array}{l}\text { Mass } R \text {. hilum extending } \\
\text { into } \mathbf{R} \text {. upper lobe }\end{array}$ & $\begin{array}{l}\text { Normal superior vena cava and main } \mathbf{R} \text {. pulmonary } \\
\text { artery }\end{array}$ & Pneumonectomy \\
\hline
\end{tabular}

TABLE II

ANGIOCARDIOGRAPHIC FINDINGS IN 11 CASES OF BRONCHIAL CARCINOMA INOPERABLE AT THORACOTOMY

\begin{tabular}{|c|c|c|c|}
\hline Case & Site of Lesion & Angiocardiographic Findings & Thoracotomy \\
\hline 21 & $\begin{array}{l}\text { Atelectasis L. lower lobe } \\
\text { with L. hilar mass }\end{array}$ & $\begin{array}{l}\text { Normal superior vena cava. Complete block } \mathbf{L} \text {. } \\
\text { main pulmonary artery }\end{array}$ & $\begin{array}{l}\text { Very large mass of glands in concavity of aortic arch } \\
\text { surrounding bronchus and main } L \text {. pulmonary } \\
\text { artery producing occlusion of pulmonary artery }\end{array}$ \\
\hline 22 & Large hilar mass & $\begin{array}{l}\text { Filling defect medial aspect superior vena cava with } \\
\text { flattening upper border R. atrium }\end{array}$ & $\begin{array}{l}\text { Growth round superior vena cava and arch of } \\
\text { azygos vein }\end{array}$ \\
\hline 23 & Atelectasis L. upper lobe & $\begin{array}{l}\text { Normal superior vena cava. Complete block } L \text {. } \\
\text { main pulmonary artery }\end{array}$ & $\begin{array}{l}\text { Mass closely adherent to aortic arch with obstruc- } \\
\text { tion of pulmonary artery }\end{array}$ \\
\hline 24 & $\begin{array}{l}\text { Mass R. lower lobe and } \\
\text { R. hilum }\end{array}$ & $\begin{array}{l}\text { Normal superior vena cava, deformity } R \text {. main } \\
\text { pulmonary artery }\end{array}$ & $\begin{array}{l}\text { Mass in hilum extending forward over upper part of } \\
\text { pericardium and into mediastinum in front of } \\
\text { bronchus }\end{array}$ \\
\hline 25 & $\begin{array}{l}\text { Mass R. upper lobe and } \\
\text { R. hilum }\end{array}$ & $\begin{array}{l}\text { Superior vena cava deformity, } R \text {. main pulmonary } \\
\text { artery deformed proximal to bifurcation, block } \\
\mathbf{R} \text {. upper lobe branches of pulmonary artery }\end{array}$ & $\begin{array}{l}\text { Mass of glands } 3 \text { in. in length between trachea and } \\
\text { superior vena cava which extended down on to } \\
\text { main bronchus and pulmonary artery }\end{array}$ \\
\hline 26 & Atelectasis R. upper lobe & $\begin{array}{l}\text { Normal superior vena cava, block R. main pul- } \\
\text { monary artery }\end{array}$ & $\begin{array}{l}\text { Growth round superior vena cava and azygos arch, } \\
\text { new growth between bronchus and upper lobe } \\
\text { division } R \text {. pulmonary artery }\end{array}$ \\
\hline 27 & Mass L. hilum & $\begin{array}{l}\text { Normal superior vena cava, complete block } \mathbf{L} \text {. } \\
\text { pulmonary artery }\end{array}$ & $\begin{array}{l}\text { Large mass in hilum which almost filled the sub- } \\
\text { aortic fossa and extended along pulmonary } \\
\text { artery }\end{array}$ \\
\hline 28 & $\begin{array}{l}\text { Mass R. upper lobe and } \\
\text { R. hilum }\end{array}$ & $\begin{array}{l}\text { Superior vena cava deformity; normal filling main } \\
\text { pulmonary artery }\end{array}$ & $\begin{array}{l}\text { Widespread involvement of mediastinal glands, large } \\
\text { mass of glands in front of } R \text {. main pulmonary }\end{array}$ \\
\hline 29 & $\begin{array}{l}\text { Mass L. lower lobe and } \\
\text { L. hilum }\end{array}$ & $\begin{array}{l}\text { Normal superior vena cava, block L. main pul- } \\
\text { monary artery }\end{array}$ & $\begin{array}{l}\text { Large growth in hilum which had extended through } \\
\text { to the pleura overlying the pulmonary artery, } \\
\text { extensive invasion wall of } L \text {. auricle }\end{array}$ \\
\hline 30 & Mass L. hilum & $\begin{array}{l}\text { Normal superior vena cava, partial block } \mathbf{L} \text {. main } \\
\text { pulmonary artery with non-filling of lower lobe }\end{array}$ & $\begin{array}{l}\text { Large mass in sub-aortic fossa, the limits of which } \\
\text { could not be defined }\end{array}$ \\
\hline 31 & Mass L. upper lobe & $\begin{array}{l}\text { branches } \\
\text { Normal superior vena cava, complete block L. main } \\
\text { pulmonary artery }\end{array}$ & \\
\hline
\end{tabular}




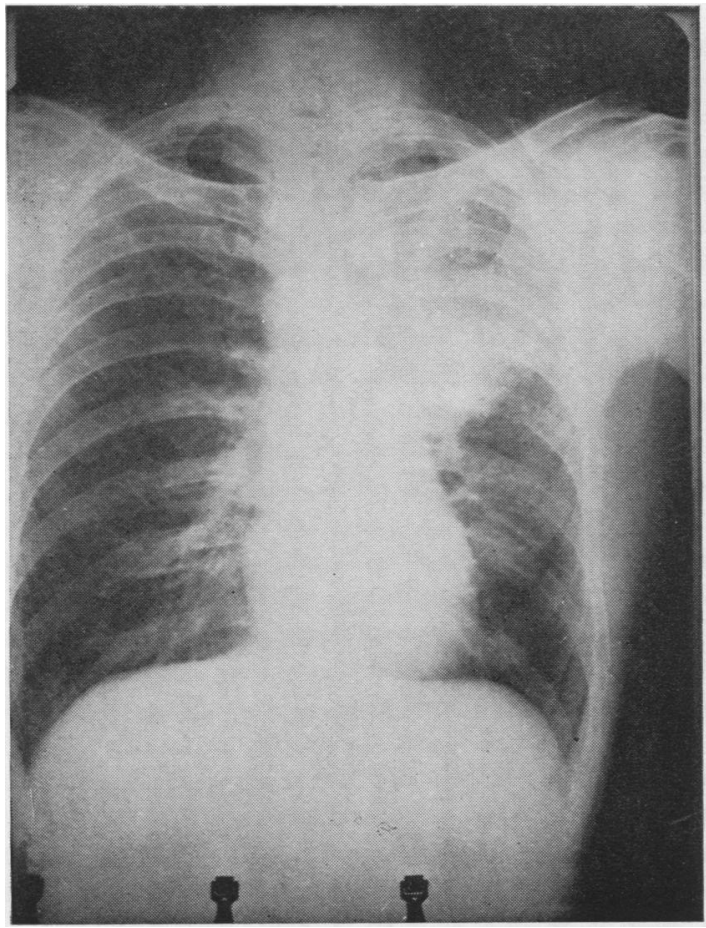

Fig. 1.-Case 2: mass in the upper left lobe in a straight film.

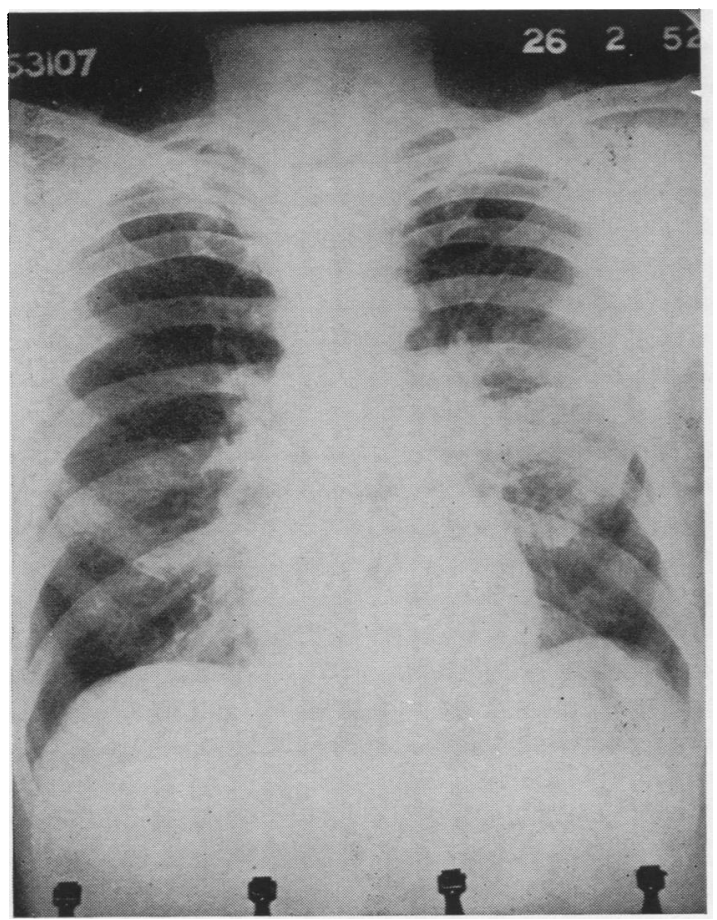

Fig. 2.-Case 6: mass left hilum in straight film.

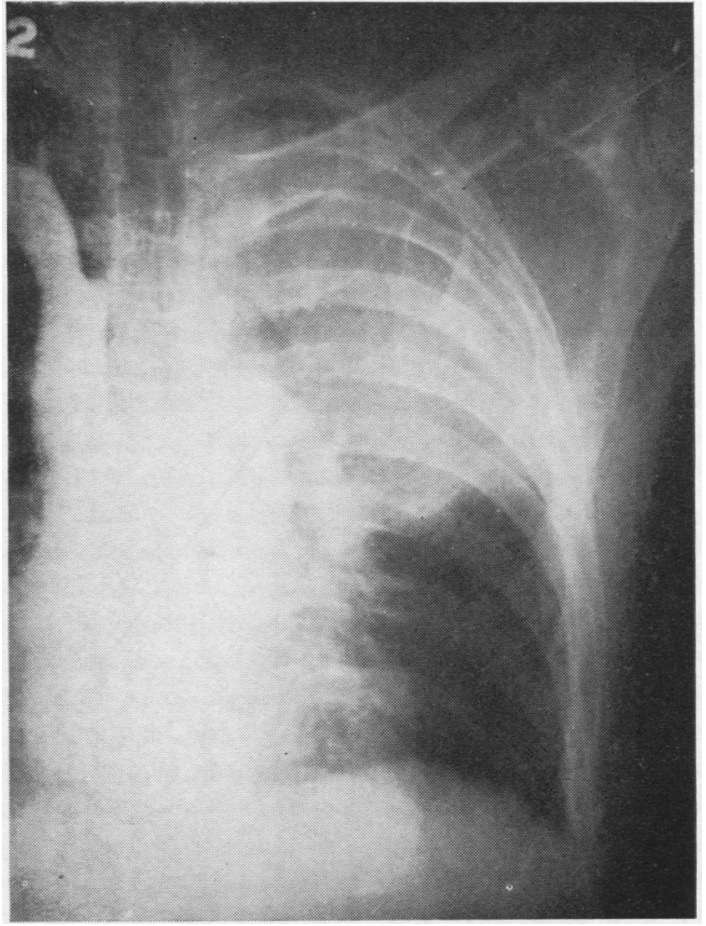

Fig. 1a.-Case 2: normal left main pulmonary artery, non-filling left upper lobe, filling left lower lobe branches in angiocardic gram.

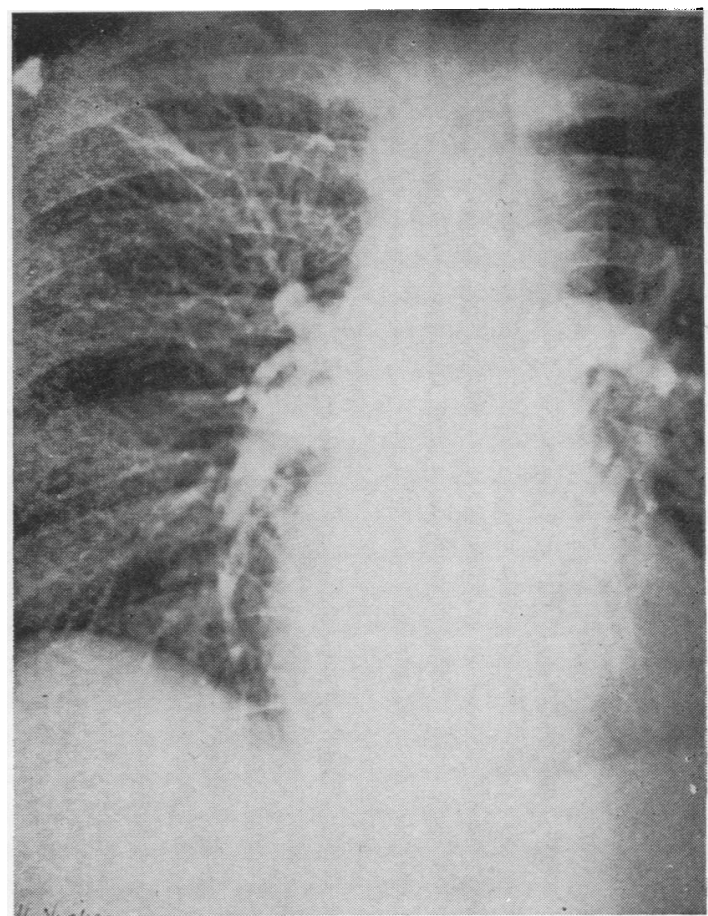

FIG. 2a.-Case 6: normal superior vena cava and pulmonary filling in angiocardiogram. 
FIG. 3.-Case 21: atelectasis in left lower lobe with left hilar mass seen in straight film.

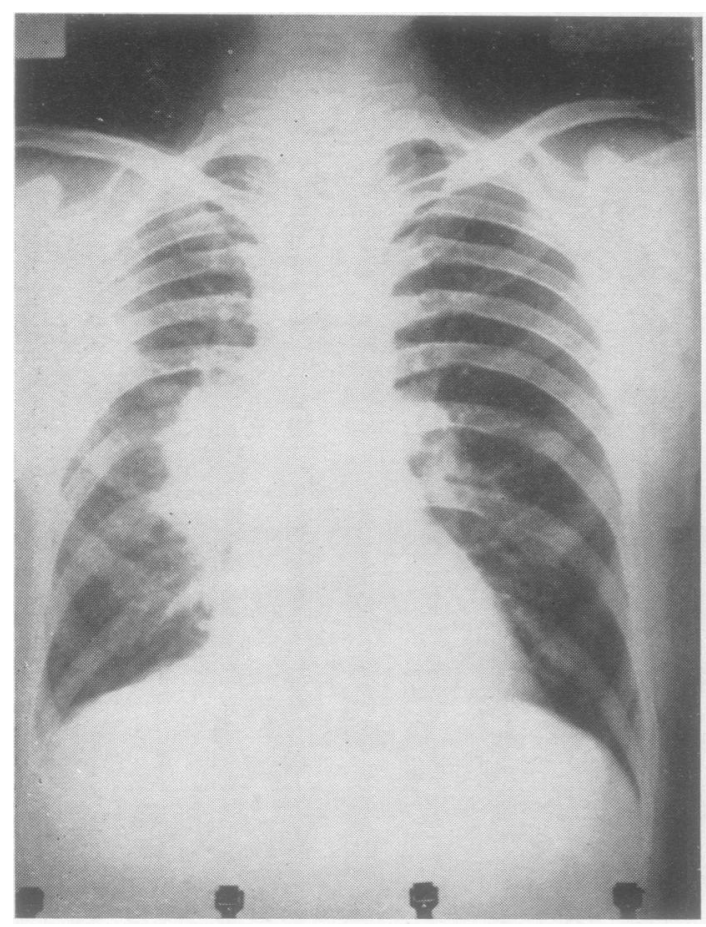

FIG. 4.-Case 22: large hilar mass in straight film.

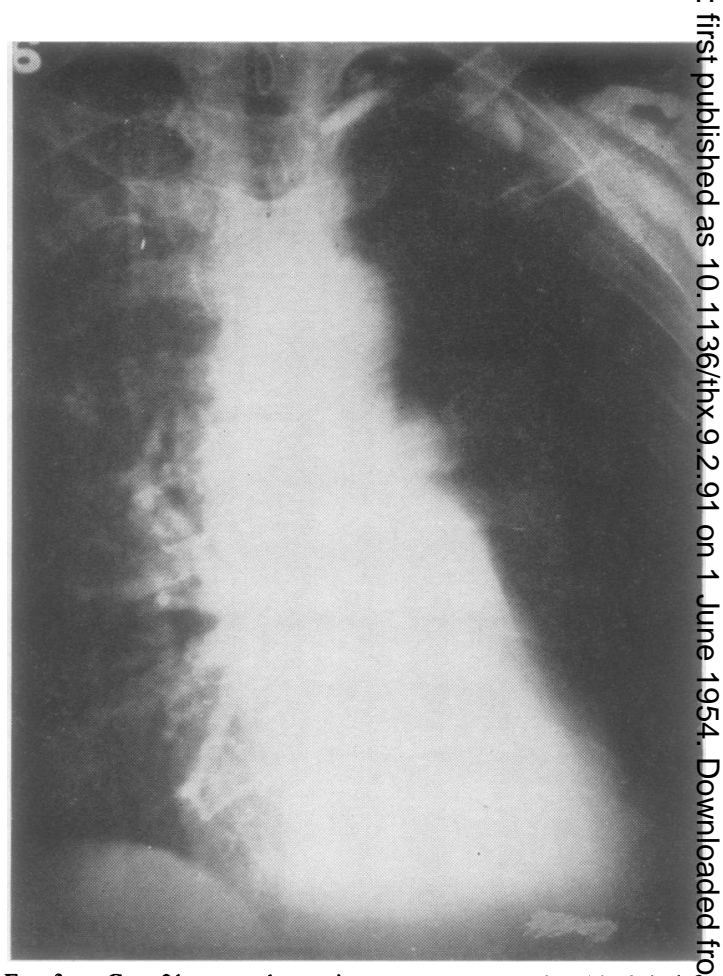

FIG. 3a.-Case 21 : normal superior vena cava; complete block in leț main pulmonary artery in angiocardiogram.

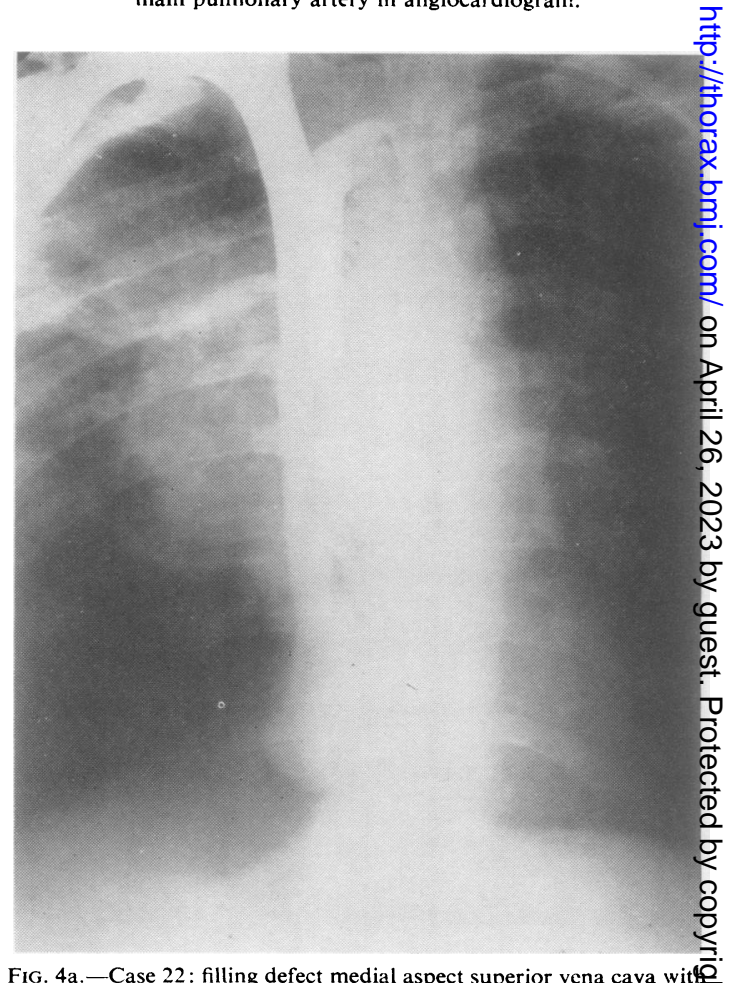

Fig. 4a.-Case 22: filling defect medial aspect superior vena cava wit flattening of upper border of the right atrium in angiocardiogram. 


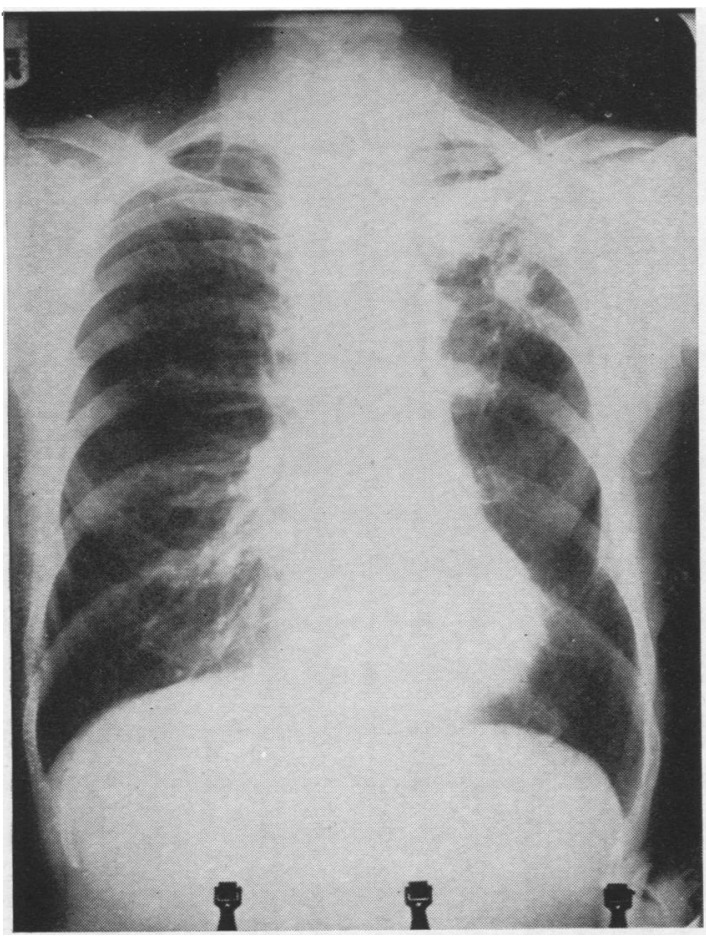

Fig. 5.-Case 23: atelectasis seen in left upper lobe in straight film.

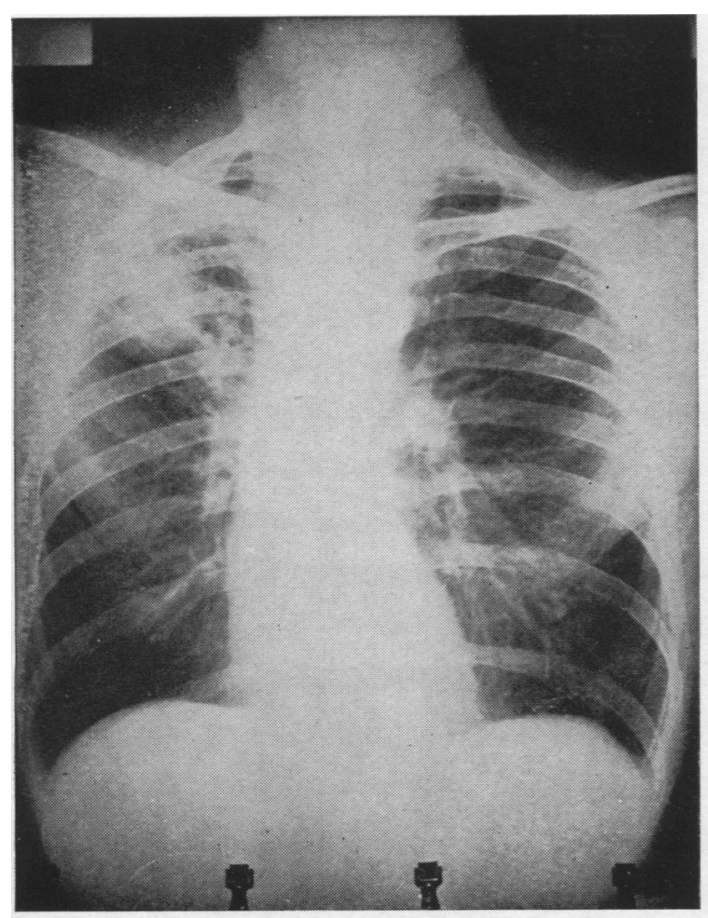

Fig. 6.-Case 25: mass in the right upper lobe and right hilum in a straight film.

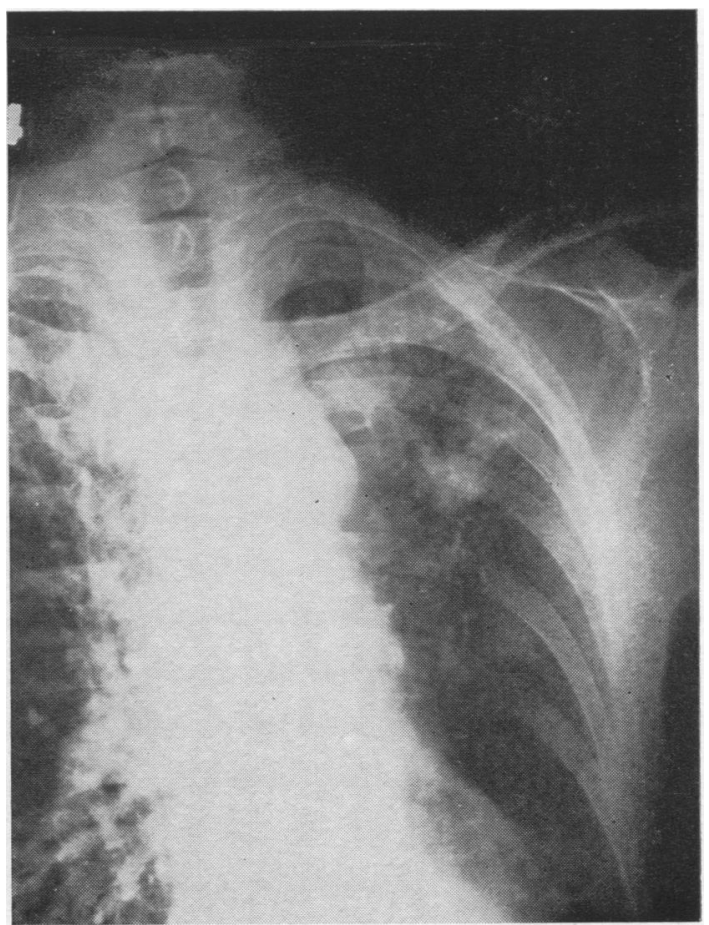

FIG. 5a.-Case 23: normal superior vena cava but complete block in the left main pulmonary artery in the angiocardiogram.

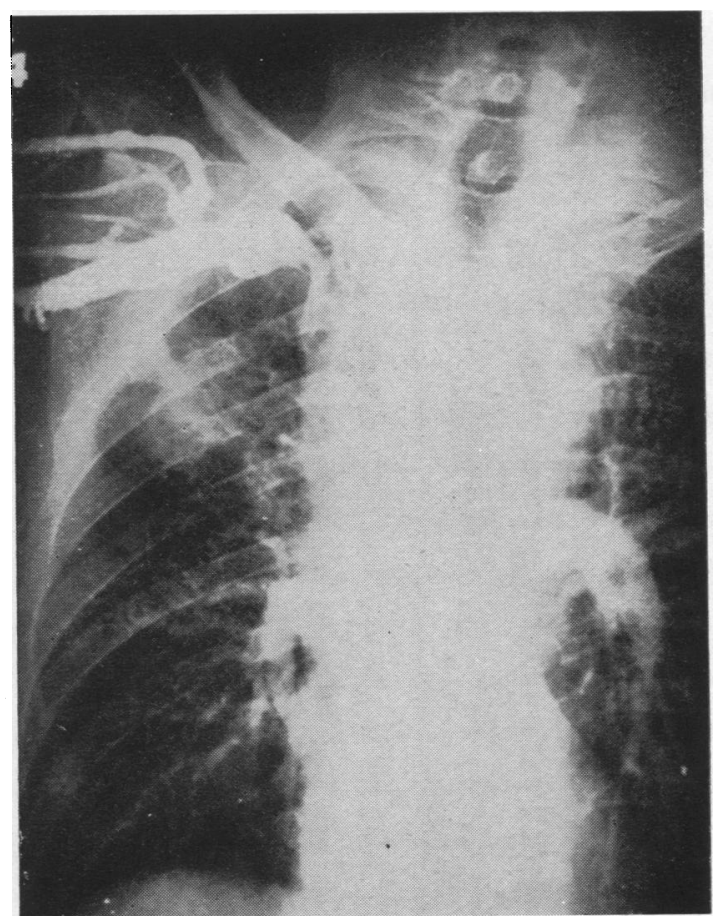

FiG. 6a.-Case 25: superior vena cava deformity and the right main pulmonary artery deformed proximal to its bifurcation, and a
block in the right upper lobe branches of the pulmonary artery are seen in the angiocardiogram. 


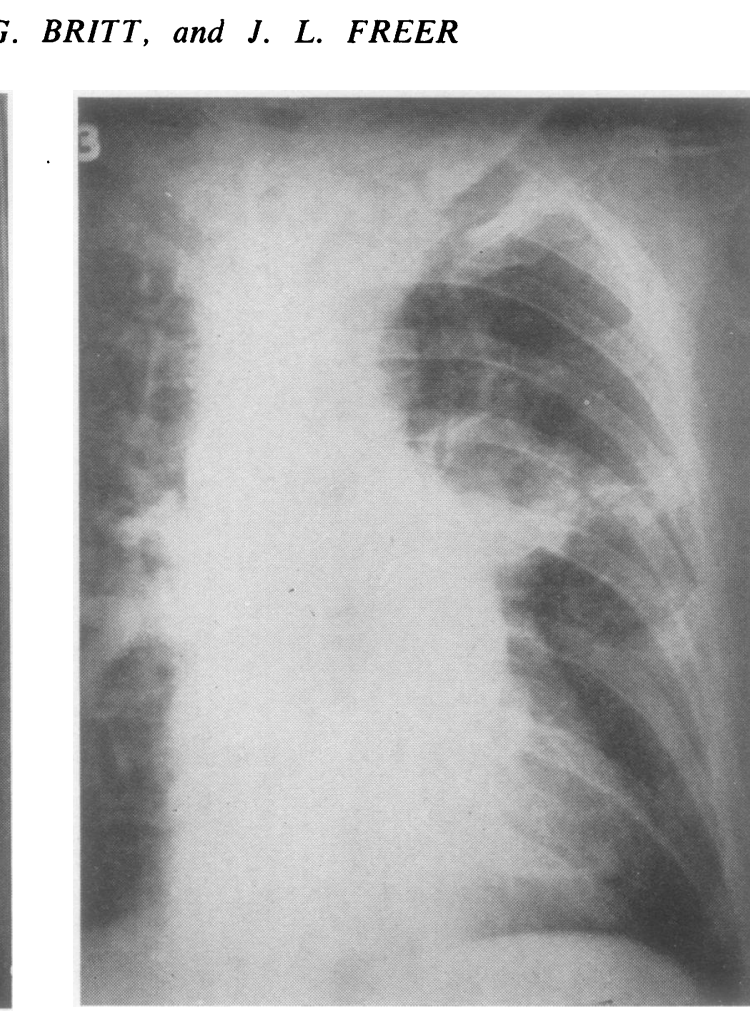

Fig. 7.-Case 27: mass in the left hilum seen in a straight film.

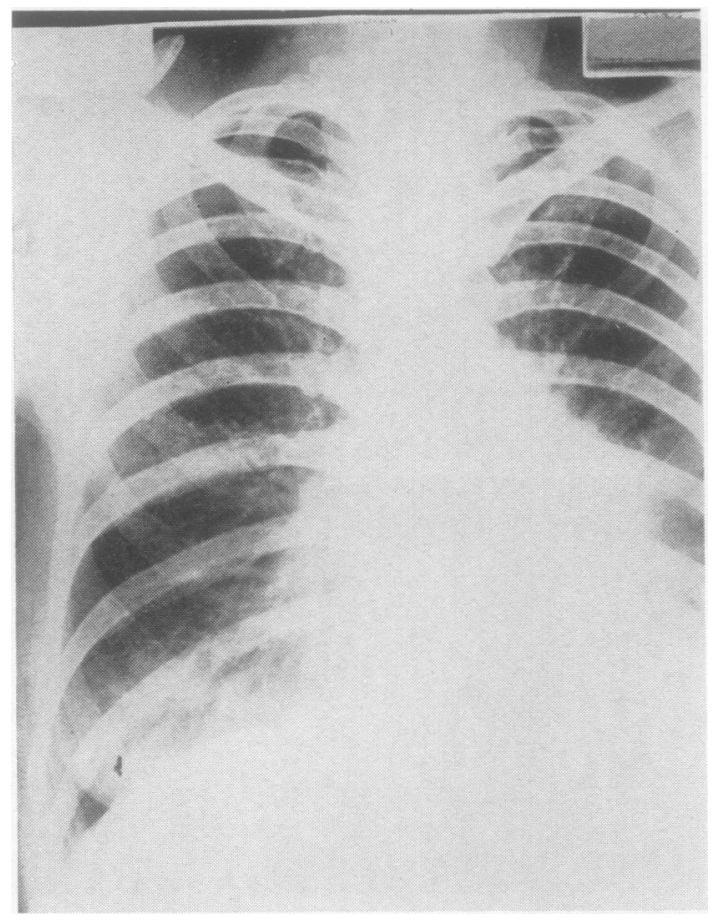

Fig. 8.-Case 29: mass in the lower left lobe and left hilum seen in a straight film.

FIG. 7a.-Case 27: normal superior vena cava and complete block ô the left pulmonary artery seen in the angiocardiogram.

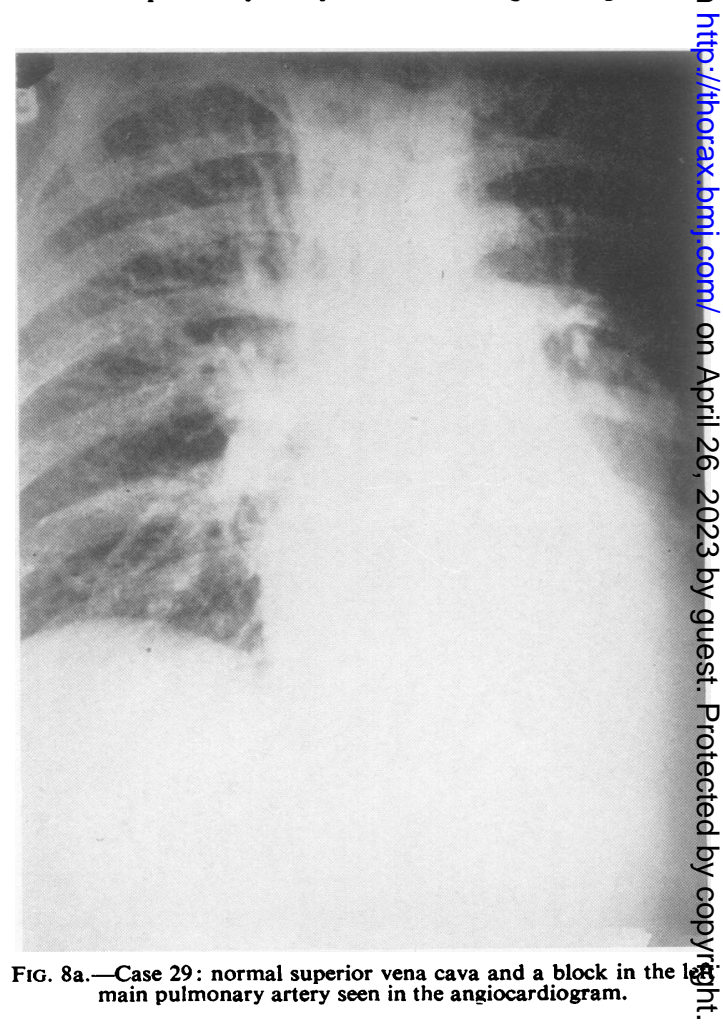




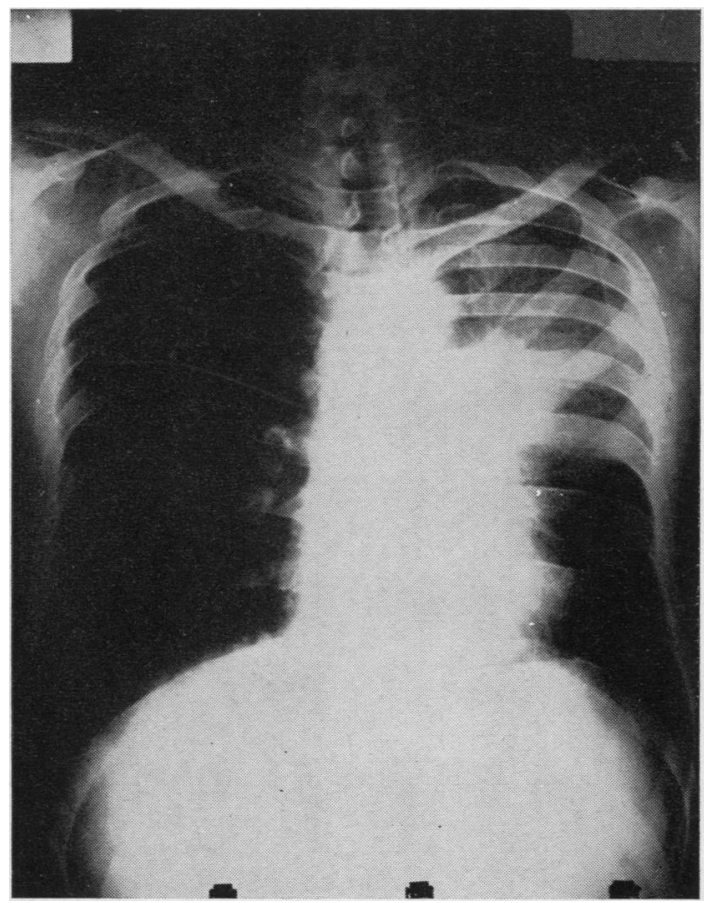

Fig. 9.-Case 31 : mass in the left upper lobe seen in a straight film.

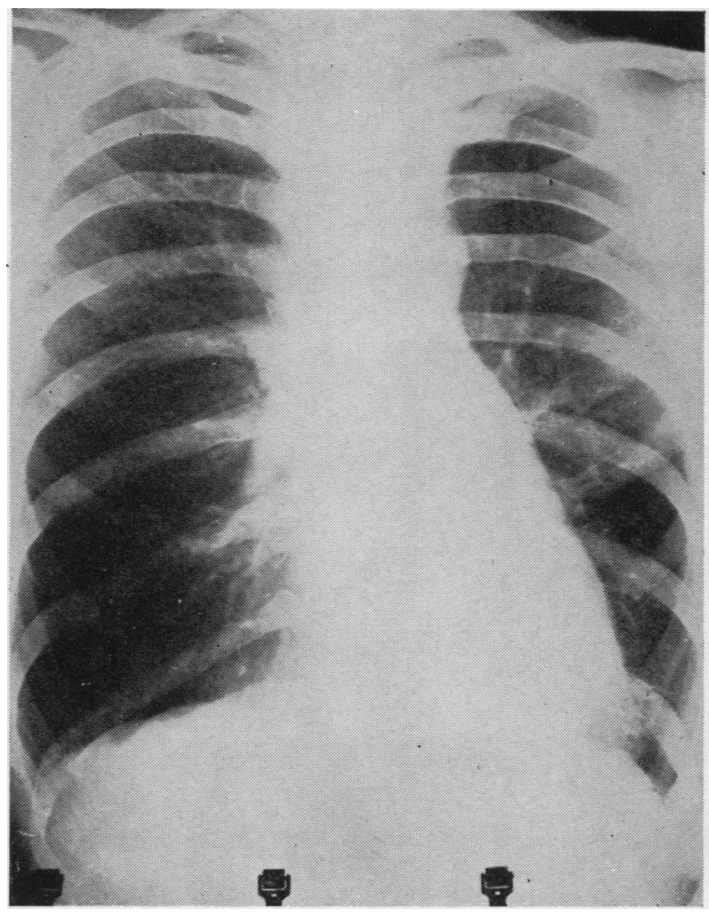

FIG. 10.-Case 8: atelectasis of left lower lobe seen in straight film.

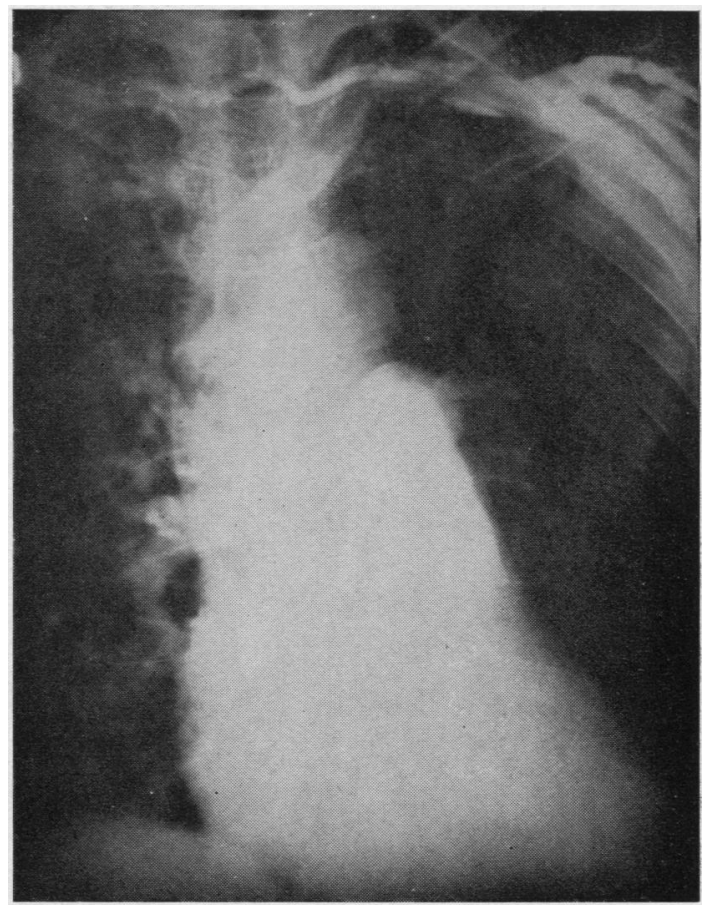

Fig. 9a.-Case 31: normal superior vena cava and complete block in the left main pulmonary artery seen in the angiocardiogram.

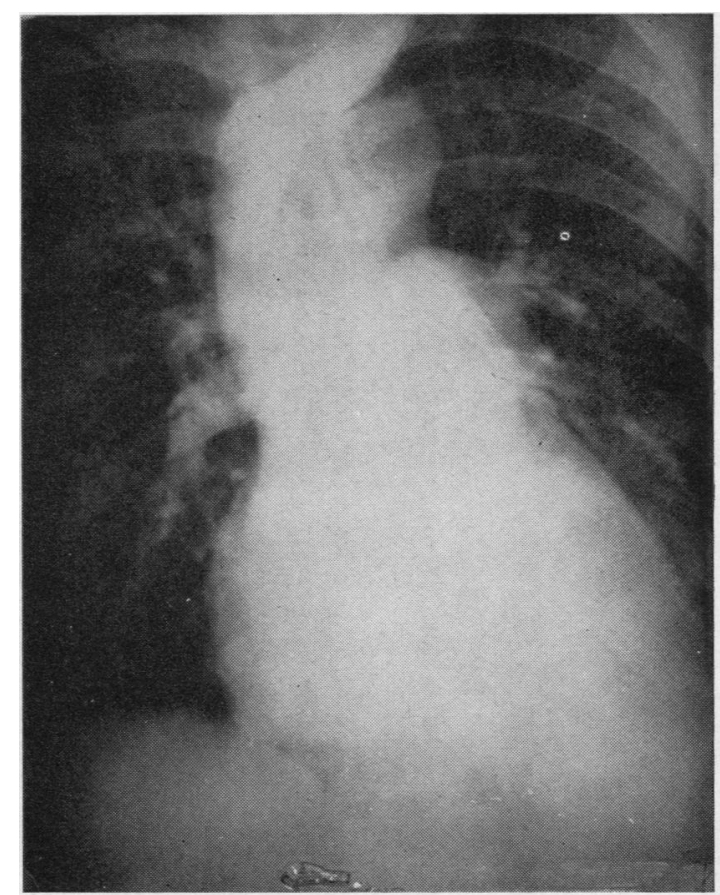

Fig. 10a.-Case 8 : normal superior vena cava and pulmonary artery. 


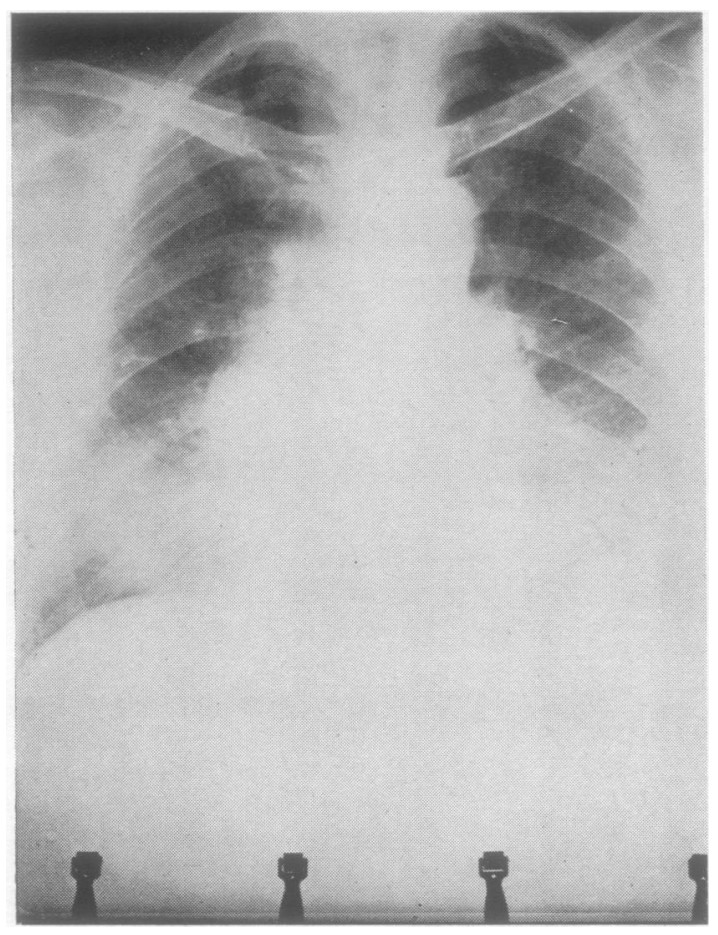

Fig. 11.-Case 17: mass in the dorsal apical segment of the right lower lobe and a right hilar mass seen in a straight film.

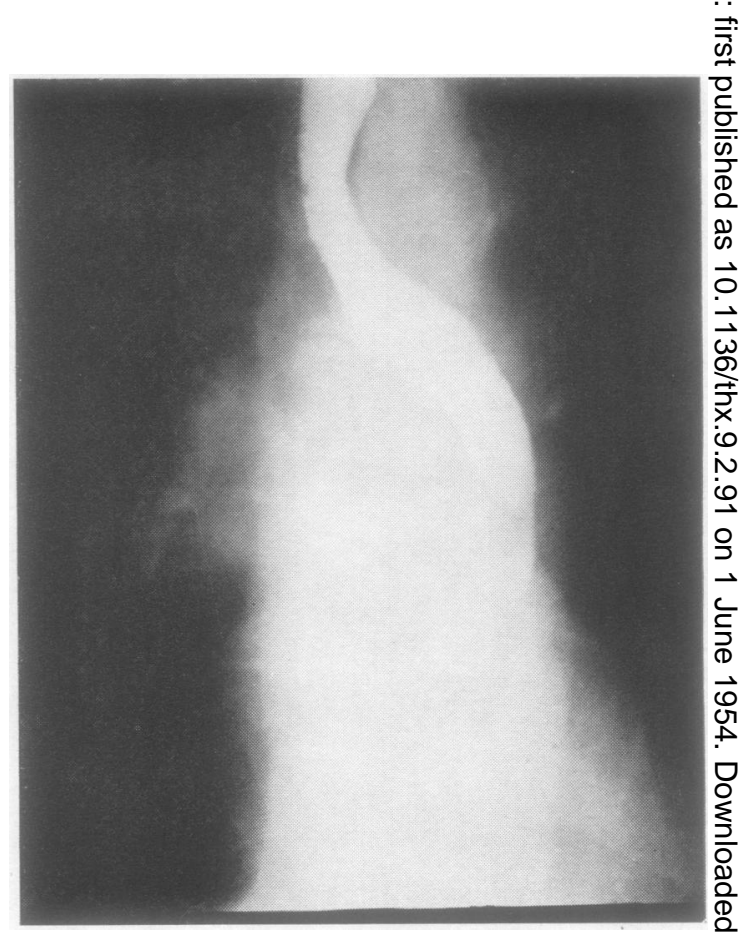

FIG. 11a.-Case 17: marked oesophageal displacement seen in $\mathrm{a}=$ barium swallow film.

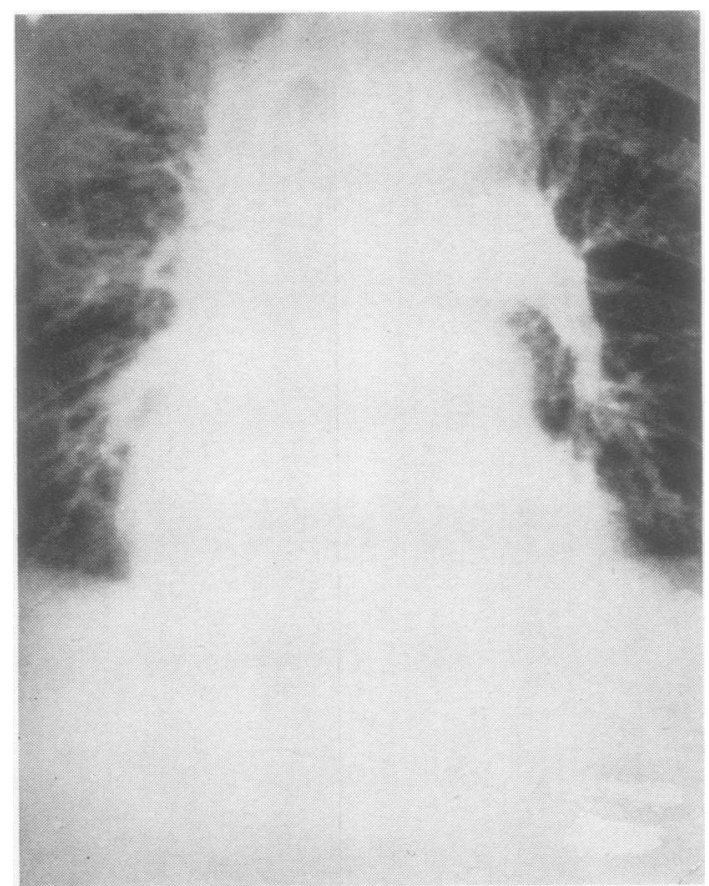

Fig. 11b.-Case 17: normal superior vena cava and main pulmonary artery seen in an angiocardiogram. 
all to no purpose. At the same time, surgery offers the only reasonable hope of a cure, except possibly in the more rapidly growing radio-sensitive types of growths, and it is a grave responsibility to refuse a patient the chance of an exploratory thoracotomy.

Certain routine procedures are used in the assessment of operability in all cases of cancer of the lung. The clinical and bronchoscopic assessment of inoperability is clear cut. However, the scope of pulmonary resection has increased quite considerably in the last decade and certain radiological findings previously considered as diagnostic of inoperability are no longer necessarily so. A growth of a lower lobe producing paralysis of the phrenic nerve can usually be resected by intrapericardial dissection and removal of the underlying pericardium. The value of barium swallow has been much discussed, and Middlemass (1953) states that in his series "thoracotomy has never yet revealed a resectable growth in a case which showed marked oesophageal displacement." We do not entirely agree with this statement, and feel that barium swallow has been of little value in assessing operability in our series. There is, however, a group of patients in whom, despite all routine investigations, the decision is still in doubt. This group consists mainly of patients with carcinoma of the lung situated at, or adjacent to, the hilum. Experience suggests that a growth in this position may well be inoperable by virtue of mediastinal invasion beyond the limits of surgical resectability. In such cases we have used angiocardiography as an adjunct to the routine investigation.

We feel that in those cases with no bronchoscopic evidence of inoperability, and where the angiocardiogram has shown no invasion of the main pulmonary artery or vena cava, it has been possible to resect the lung although the pulmonary vein may require intrapericardial ligation. It is not suggested that in every angiocardiogram there is a clear division into operable and inoperable groups, but in those cases which were regarded as a borderline decision pneumonectomy has proved possible. Where the angiocardiogram has demonstrated involvement of a main pulmonary artery or great vein it has been found at thoracotomy that the growth has progressed beyond the limits of surgical resectability.

\section{SUMmary}

Venous angiocardiography was performed on 31 patients with bronchial neoplasm. Twenty patients showed no deformity of the main pulmonary artery or superior vena cava and were considered operable ; this was confirmed at thoracotomy. Three patients had deformity of the superior vena cava and inoperability was confirmed at thoracotomy. The remaining eight patients showed deformity of the main pulmonary artery and these cases were also found to be inoperable at thoracotomy.

All of these patients were operable on clinical and bronchoscopic grounds.

We wish to thank Mr. L. G. Cruickshank, F.R.C.S., surgeon, Leicester Chest Unit, for his help and advice in this investigation and for allowing access to his cases.

\section{REFERENCES}

Andersen, P. T., Andersen, I., Eltorm, H., Poulsen, T., Glistrup, E., and Petersen, H. (1951). Acta radiol., Stockh., 36, 257.

Dotter, C. T., and Steinberg, I. (1952). Ann. Roentgenol., 20, Angiocardiography, p. 267.

Middlemass, I. B. D. (1953). J. Fac. Radiol., Lond., 5, 121.

Robb, G. P., and Steinberg, I. (1938). J. clin. Invest., 17, 507

Steinberg, I., Dotter, C. T., and Andrus, W. DeW. (1950). Surg. Gynec. Obstet., 90, 45. 